\title{
Pengaruh Bimbingan Kelompok dengan Teknik Diskusi dalam Meningkatkan Konsep Diri Positif Siswa
}

\author{
Weli Marista ${ }^{1}$, M. Ferdiansyah ${ }^{2}$, Nurlela ${ }^{3}$
}

${ }^{123}$ Bimbingan dan Konseling, Universitas PGRI Palembang, Indonesia

${ }^{(1)}$ Wellymarista@gmail.com, ${ }^{(2)}$ mferdiansyah34@yahoo.com ${ }^{\left({ }^{(3)}\right.}{ }^{\text {nurlelampd97@gmail.com }}$

$\begin{array}{ccc}\text { First received: } & \text { Revised: } & \text { Final Accepted: } \\ \text { 01 September 2021 } & 12 \text { November 2021 } & \text { 14 Desember 2021 }\end{array}$

\begin{abstract}
Self-concept is an individual's understanding of himself physically and psychologically including the advantages and disadvantages he has. This study aims to determine the effectiveness of group guidance services using discussion techniques to improve students' positive self-concepts. This study uses a quantitative approach and the method used in this study is a pre-experimental design study with one group pretest and posttest design. This research was conducted at SMK Muhammadiyah 2 Palembang, and the samples of this research were students of class XII AKL 2 which amounted to 32 students after being given a pretest taken as many as 8 students who had a low positive self-concept. Sampling using a random sample technique. The results of the study were tested with the Wilcoxon Signed Rank Test statistic which was used to measure the significance of the difference between 2 groups in paired data on an ordinal or interval scale but with a non-normal data distribution. Based on the table of results of the Wilcoxon Signed Rank Test analysis, it can be seen that the Asymp probability number. Sig. (2-tailed) students' academic procrastination in doing assignments is 0.012 , or the probability is below alpha 0.05 $(0.012 \leq 0.05)$. From the results obtained, Ho is rejected and Ha is accepted. Thus, it shows that group guidance with discussion techniques is effective in increasing students' positive self-concept.
\end{abstract}

Keywords: Group Guidance, Discussion Techniques, Self-Concept

\begin{abstract}
Abstrak
Konsep diri adalah pemahaman individu terhadap dirinya secara fisik maupun psikologis termasuk kelebihan dan kekurangan diri. Penelitian ini bertujuan untuk mengetahui keefektifan layanan bimbingan kelompok menggunakan teknik diskusi untuk meningkatkan konsep diri positif siswa. Penelitian ini menggunakan pendekatan kuantitatif dan metode yang digunakan dalam penelitian ini adalah penelitian preexperimental design dengan one grup pretest dan posttest design. Penelitian ini dilaksanakan di SMK Muhammadiyah 2 Palembang, dan yang menjadi sampel penelitian ini adalah siswa kelas XII AKL 2 yang berjumlah 32 orang siswa setelah diberikan pretest diambil sebanyak 8 orang siswa yang memiliki konsep diri positif rendah. Pengambilan sampel menggunakan teknik random sample. Hasil penelitian diuji dengan statistik Wilcoxon Signed Rank Test digunakan untuk mengukur signifikasi perbedaan antara 2 kelompok pada data berpasangan bersekala ordinal atau interval tetapi dengan distribusi data tidak normal. Berdasrkan tabel hasil analisis Wilcoxon Signed Rank Test, terlihat angka probabilitas Asymp. Sig. (2-tailed) prokratinasi akademik siswa dalam mengerjakan tugas sebesar 0.012 , atau probabilitas dibawah alpha $0,05(0,012 \leq 0,05)$. Dari hasil yang diperoleh maka Ho ditolak dan Ha diterima. Dengan demikian menunjukan bahwa bimbingan kelompok dengan teknik diskusi efektif untuk meningkatkan konsep diri positif siswa.
\end{abstract}

Kata Kunci : Bimbingan Kelompok, Teknik Diskusi, Konsep Diri 


\section{PENDAHULUAN}

Sekolah sebagai salah satu lembaga pendidikan yang harus berkewajiban menyelenggarakan proses atau kegiatan belajar mengajar yang melibatkan peserta didik secara menyeluruh. Proses belajar di dalam kelas merupakan aktivitas memindahkan pengetahuan, ilmu, sikap, dan keterampilan. Dalam pembelajaran tersebut guru hendaklah dapat mengembangkan kemampuan peserta didik, kompotensi dasar dan potensi yang dimiliki peserta didik secara utuh.

Peserta didik pada usia remaja di sekolah menengah atas sebagai individu yang sedang berkembang mencapai taraf perkembangan pribadi secara optimal dalam berbagai aspek kehidupan. Pada usia ini guru diharapkan dapat mengembangkan kreatifitas peserta didik sehingga peserta didik lebih aktif dalam proses belajar mengajar dan dapat mengembangkan ide, pikiran, serta belajar mandiri. Biasanya usia peserta didik 15-17 tahun sering bertanya tentang sesuatu yang belum mereka pahami, mereka memiliki rasa ingin tahu yang lebih tinggi dan pada usia ini juga peserta didik masih kesulitan untuk memutuskan suatu hal yang lebih baik.

Bimbingan dan konseling memiliki peranan penting berkaitan dengan pemenuhan fungsi dan tujuan pendidikan serta peningkatan mutu pendidikan di sekolah. Bimbingan dan konseling sebagai rangkaian upaya pemberian bantuan pada peserta didik untuk mencapai perkembangan optimal. Dalam memutuskan hal, peserta didik membutuhkan bimbingan untuk diarahkan kesuatu hal yang lebih baik. peserta didik membutuhkan arahan dari guru untuk menilai sesuatu yang belum mereka pahami. Salah satu hal yang dapat diarahkan guru terhadap peserta didik ialah membantu dalam memecahkan masalah yang sedang dihadapinya tersebut, salah satunya dengan diberikannya bimbingan kelompok (Hadi:62:2019).

Teknik merupakan salah satu cara atau model tertentu utnuk pencapain tujuan. Diskusi merupakan pertukaran gagasan, pendapat, ataupun pikiran antara dua orang atau lebih secara lisan yang bertujuan untuk mencari kesepakatan atau kesepahaman gagasan atau pendapat. Dalam diskusi yang terpenting adalah bahwa orang yang berdiskusi sungguh nyata dalam berkomu nikasi. Semua permasalahan tidak akan bisa diselesaikan tanpa melalui proses komunikasi (Ardana:25:2019).

Pandangan dan sikap individu terhadap dirinya inilah yang dikenal dengan konsep diri. (Rury:58:2015) Konsep diri merupakan pandangan menyeluruh individu tentang totalitas dari dirinya sendiri mengenai prinsip kehidupan dan segala yang terbentuk dari segala pengalaman dan interaksinya dengan orang lain. Siswa yang memiliki konsep diri positif dapat memahami dan menerima berbagai faktor yang sangat bermacam-macam tentang dirinya sendiri. Dalam hal ini peserta didik dapat menerima dirinya secara apa adanya dan akan mampu menginintropeksi diri atau lebih mengenal dirinya, serta kelemahan dan kelebihan yang dimiliki.

Berdasrakan uraian di atas maka peneliti tertarik untuk melakukan penelitian di SMK Muhammadiyah 2 Palembang agar dapat memahami lebih mendalam bagaimana pengaruh bimbingan kelompok dengan teknik diskusi dalam meningkatkan konsep diri positif siswa SMK Muhammadiyah 2 Palembang.

\section{METODE}


"Metode penelitian dapat di diklasifikasikan berdasarkan, tujuan, dan tingkat kealamiahan (natural aetting) objek yang diteliti. Metode penelitian yang digunakan ialah pendekatan Kuantitatif dengan metode Eksperimen yaitu PreExperimental Design. Metode Eksperimen di artikan sebagai metode penelitian yang digunakan untuk mencari pengaruh perilaku tertentu terhadap yang lain dalam kondisi yang terkendalikan (Sugiono 2018:9)". Maka metode penelitian ini menggunakan Pre-experimen Design dengan One Grup pretest dan Posttetst Design.

"Sampel adalah sebagian atau wakil populasi yang diteliti. Dinamakan penelitian sampel apabila kita bermaksud untuk menggeneralisasikan hasil penelitian sampel. Yang di maksud dengan menggeneralisasikan adalah kesimpulan penelitian sebagai suatu yang berlaku bagi populasi" (Arikunto 2014:174). Dari jumlah populasi yang akan di teliti di kelas XII di atas, maka teknik pengambilan sampel dalam penelitian ini menggunakan sampel campur atau Random Sample. Pemilihan berdasarkan atas pertimbangan bahwa pengambilan sampel dengan teknik ini dapat mencampur subjek-subjek di dalam populasi sehingga semua subjek di anggap sama. Dengan demikian peneliti memberi hak yang sama kepada setiap subjek untuk memperoleh kesempatan dipilih terlepas dari perasaan ingin mengistimewakan satu atau beberapa subjek subjek untuk dijadikan sampel. Untuk mempermudah pengambilan sampel maka dapat menggunakan: undian.

Tabel 2

Sampel Penelitian

\begin{tabular}{|l|l|l|l|l|}
\hline No & Kelas & \multicolumn{2}{|c|}{ Jenis Kelamin } & Jumlah \\
\cline { 3 - 4 } & $\begin{array}{c}\text { Laki- } \\
\text { laki }\end{array}$ & perempuan & \\
\hline
\end{tabular}

\begin{tabular}{|l|l|l|l|l|}
\hline 2 & XII & 4 & 28 & 32 \\
& AKL & & & \\
2 & & & \\
\hline
\end{tabular}

Oleh karena itu dalam penelitian ini mengambil 8 orang sampel dari kelas XII SMK Muhammadiyah 2 Palembang. seluruh populasi dengan pertimbangan 8 orang tersebut memiliki konsep diri positif yang rendah.

\section{HASIL TEMUAN}

Berdasarkan data yang diperoleh yang telah dilakukan analisis data, dan dicari interval maka di peroleh hasil berikut: (Irianto:2012:12)

Interval kelas $=\frac{\text { data terbesar-data terkecil }}{\text { jumlah skor }}$ $=\frac{104-73}{5}=6,2$

Berdasarkan hasil perhitungan, maka diperoleh interval skor yang di dapatkan adalah 8 .

Tabel 6 Kategorisasi Skor

\begin{tabular}{|c|c|c|c|}
\hline No & Skor & $\%$ & Kategori \\
\hline 1 & $\geq 105$ & $\geq 91$ & $\begin{array}{c}\text { Sangat } \\
\text { Tinggi }\end{array}$ \\
\hline 2 & $97-104$ & $84-90$ & Tinggi \\
\hline 3 & $89-96$ & $77-83$ & Sedang \\
\hline 4 & $81-88$ & $70-76$ & Rendah \\
\hline 5 & $73-80$ & $63-69$ & $\begin{array}{c}\text { Sangat } \\
\text { Rendah }\end{array}$ \\
\hline
\end{tabular}

Pretest diberikan sebelum perlakuan kepada kelompok eksperimen yang bertujuan untuk mengetahui kondisi tingkat konsep diri positif siswa kelas XII SMK Muhammadiyah 2 Palembang. Untuk mengetahui gambaran awal, disajikan kondisi pretest tingkat konsep diri positif siswa kelas XII SMK Muhammadiyah 2 Palembang.

Tabel 7 Hasil Preetest

\begin{tabular}{|l|l|l|l|}
\hline No & $\begin{array}{l}\text { Nama } \\
\text { Siswa }\end{array}$ & Skor & Kriteria \\
\hline 1 & AEP & 95 & Sedang \\
\hline 2 & AW & 95 & Sedang \\
\hline
\end{tabular}




\begin{tabular}{|l|l|l|l|}
\hline 3 & AP & 96 & Sedang \\
\hline 4 & A & 103 & Tinggi \\
\hline 5 & AA & 80 & Sangat Rendah \\
\hline 6 & BS & 94 & Sedang \\
\hline 7 & CC & 96 & Sedang \\
\hline 8 & DPS & 94 & Sedang \\
\hline 9 & D & 73 & Sangat Rendah \\
\hline 10 & DHPS & 75 & Sangat Rendah \\
\hline 11 & DM & 88 & Rendah \\
\hline 12 & EYR & 88 & Rendah \\
\hline 13 & FNA & 101 & Tinggi \\
\hline 14 & FA & 87 & Rendah \\
\hline 15 & FD & 99 & Tinggi \\
\hline 16 & FH & 93 & Sedang \\
\hline 17 & IK & 92 & Sedang \\
\hline 18 & IYS & 76 & Sangat Rendah \\
\hline 19 & IP & 102 & Tinggi \\
\hline 20 & K & 77 & Sangat Rendah \\
\hline 21 & LN & 99 & Tinggi \\
\hline 22 & M & 97 & Tinggi \\
\hline 23 & M & 101 & Tinggi \\
\hline 24 & MS & 78 & Sangat Rendah \\
\hline 25 & M & 103 & Tinggi \\
\hline 26 & NV & 97 & Tinggi \\
\hline 27 & NA & 104 & Tinggi \\
\hline 28 & RA & 96 & Sedang \\
\hline 29 & SC & 99 & Tinggi \\
\hline 30 & YE & 96 & Sedang \\
\hline 31 & YS & 81 & Rendah \\
\hline 32 & ZJ & 100 & Tinggi \\
\hline (Sumber $;$ Hasil Olah Data Terlampir) \\
\hline
\end{tabular}

Berdasarkan hasil preetest dari kelas XII Akl 2 dengan jumlah 32 orang siswa yang memiliki konsep diri dalam kategori "Sedang ". Berdasrkan data di atas dapat disimpulkan bahwa yang memiliki konsep diri positif siswa dengan kategori "Rendah" dan "Sangat Rendah"di ambil 8 orang yang akan dijadikan sampel Posttest untuk diberikan treatment perlakuan.

Hasil pree-test dapat di persentasekan dalam tabel sebagai berikut: Tabel 8 Distribusi Frekuensi Konsep Diri Positif Siswa

\begin{tabular}{|c|c|c|c|c|}
\hline \multicolumn{5}{|c|}{ Data Preetest } \\
\hline No & Skor & Kriteria & $\begin{array}{l}\text { XII } \\
\text { AKL } \\
2 \\
\text { (F) }\end{array}$ & $\%$ \\
\hline 1 & $>105$ & $\begin{array}{l}\text { Sangat } \\
\text { Tinggi }\end{array}$ & - & - \\
\hline 2 & $\begin{array}{l}97- \\
104\end{array}$ & Tinggi & 12 & $37 \%$ \\
\hline 3 & $\begin{array}{ll}89 & - \\
96 & \end{array}$ & Sedang & 10 & $32 \%$ \\
\hline 4 & $\begin{array}{ll}81 & - \\
88 & \end{array}$ & Rendah & 4 & $12 \%$ \\
\hline 5 & $\begin{array}{ll}73 & - \\
80 & \\
\end{array}$ & $\begin{array}{l}\text { Sangat } \\
\text { Rendah }\end{array}$ & 6 & $19 \%$ \\
\hline \multicolumn{3}{|c|}{ Jumlah Siswa } & 32 & $100 \%$ \\
\hline \multicolumn{3}{|c|}{ Jumlah Skor } & \multicolumn{2}{|c|}{2955} \\
\hline \multicolumn{3}{|c|}{ Rata-rata } & \multicolumn{2}{|c|}{$\begin{array}{l}92,34 \\
\text { (Sedang) }\end{array}$} \\
\hline
\end{tabular}

Berdasarkan tabel tersebut maka dapat diperoleh persentase tingkat konsep diri positif siswa kelas XII AKL 2 adalah $37 \%$ dengan kategori " Sedang " dan memiliki rata-rata 92,34. Jadi, berdasrkan data di atas dapat disimpulkan bahwa yang memiliki konsep diri positif siswa dengan kategori "Rendah" dan "Sangat Rendah"di ambil 8 orang yang akan dijadikan sampel Posttest untuk diberikan treatment perlakuan

Data penelitian yang diperoleh dari pembagian angket yang diberikan kepada 32 orang siswa kelas XII AKL 2. Berikut data hasil treatment:

Tabel 9 Data Treatment

\begin{tabular}{|l|l|l|l|}
\hline No & $\begin{array}{l}\text { Nama } \\
\text { Siswa }\end{array}$ & Skor & Kriteria \\
\hline 1 & AEP & 95 & Sedang \\
\hline 2 & AW & 95 & Sedang \\
\hline 3 & AP & 96 & Sedang \\
\hline 4 & A & 103 & Tinggi \\
\hline 5 & AA & 80 & $\begin{array}{l}\text { Sangat } \\
\text { Rendah }\end{array}$ \\
\hline
\end{tabular}




\begin{tabular}{|l|l|l|l|}
\hline 6 & BS & 94 & Sedang \\
\hline 7 & CC & 96 & Sedang \\
\hline 8 & DPS & 94 & Sedang \\
\hline 9 & D & 73 & $\begin{array}{l}\text { Sangat } \\
\text { Rendah }\end{array}$ \\
\hline 10 & DHPS & 75 & $\begin{array}{l}\text { Sangat } \\
\text { Rendah }\end{array}$ \\
\hline 11 & DM & 88 & Rendah \\
\hline 12 & EYR & 88 & Rendah \\
\hline 13 & FNA & 101 & Tinggi \\
\hline 14 & FA & 87 & Rendah \\
\hline 15 & FD & 99 & Tinggi \\
\hline 16 & FH & 93 & Sedang \\
\hline 17 & IK & 92 & Sedang \\
\hline 18 & IYS & 76 & $\begin{array}{l}\text { Sangat } \\
\text { Rendah }\end{array}$ \\
\hline 19 & IP & 102 & Tinggi \\
\hline 20 & K & 77 & $\begin{array}{l}\text { Sangat } \\
\text { Rendah }\end{array}$ \\
\hline 21 & LN & 99 & Tinggi \\
\hline 22 & M & 97 & Tinggi \\
\hline 23 & M & 101 & Tinggi \\
\hline 24 & MS & 78 & $\begin{array}{l}\text { Sangat } \\
\text { Rendah }\end{array}$ \\
\hline 25 & M & 103 & Tinggi \\
\hline 26 & NV & 97 & Tinggi \\
\hline 27 & NA & 104 & Tinggi \\
\hline 28 & RA & 96 & Sedang \\
\hline 29 & SC & 99 & Tinggi \\
\hline 30 & YE & 96 & Sedang \\
\hline 31 & YS & 81 & Rendah \\
\hline 32 & ZJ & 100 & Tinggi \\
\hline
\end{tabular}

Berdasarkan hasil Treatment dari kelas XII AKL 2 dengan jumlah 32 orang siswa yang memiliki kategori "Sedang". Berdasrkan data di atas dapat disimpulkan bahwa yang memiliki konsep diri positif siswa dengan kategori "Rendah" dan "Sangat Rendah"di ambil 8 orang yang akan dijadikan sampel Posttest. Untuk melihat adanya peningkatan atau penurunan skor akan dijadikan posttest maka diperoleh data sebagai berikut :

\begin{tabular}{|c|c|c|c|c|}
\hline No & Skor & Kriteria & (F) & $\%$ \\
\hline 1 & $>105$ & $\begin{array}{l}\text { Sangat } \\
\text { Tinggi }\end{array}$ & 2 & $25 \%$ \\
\hline 2 & $97-104$ & Tinggi & 3 & $38 \%$ \\
\hline 3 & $89-96$ & Sedang & 3 & $37 \%$ \\
\hline 4 & $81-88$ & Rendah & - & - \\
\hline 5 & $73-80$ & $\begin{array}{l}\text { Sangat } \\
\text { Rendah }\end{array}$ & - & - \\
\hline \multicolumn{3}{|c|}{ Jumlah Siswa } & 8 & $100 \%$ \\
\hline \multicolumn{3}{|c|}{ Jumlah Skor } & \multicolumn{2}{|c|}{770} \\
\hline \multicolumn{3}{|c|}{ Rata-rata } & \multicolumn{2}{|c|}{$\begin{array}{c}96,25 \\
\text { (Sedang) }\end{array}$} \\
\hline
\end{tabular}

Berdasrkan tabel hasil Posttest dari 32 orang siswa yang memiliki konsep diri positif dapat di ambil kesimpulan dalam kategori "Sedang" dengan rata-rata skor 770 dengan persentase $96,25 \%$ sebanyak 3 orang siswa.

Dalam menguji hipotesis digunakan uji non parametrik dengan menggunakan rumus Wilcoxon signed Rank Test dengan menggunakan program SPSS Versi 22.00. Uji Wilcoxon Signed Rank Test digunakan untuk mengukur signifikasi perbedaan antara 2 kelompok data tidak normal.

\section{Tabel 15 Arah Perbedaan Preetest dan Posttest Konsep Diri Positif Siswa Wilcoxon Signed Ranks Test Ranks}

\begin{tabular}{|c|c|c|c|c|}
\hline & & $\mathrm{N}$ & $\begin{array}{l}\text { Mean } \\
\text { Rank }\end{array}$ & $\begin{array}{l}\text { Sum of } \\
\text { Ranks }\end{array}$ \\
\hline \multirow{4}{*}{$\begin{array}{l}\text { Post } \\
\text { Test } \\
\text { Pre } \\
\text { Test }\end{array}$} & $\begin{array}{l}\text { Negativ } \\
\text { e Ranks }\end{array}$ & $0^{\mathrm{a}}$ & 00 & \\
\hline & $\begin{array}{l}\text { Positive } \\
\text { Ranks }\end{array}$ & $8^{b}$ & 4,50 & 36,00 \\
\hline & Ties & $0^{c}$ & & \\
\hline & Total & 8 & & \\
\hline
\end{tabular}
a. Post Test < Pre Test
b. Post Test $>$ Pre Test
c. Post Test $=$ Pre Test 
Berdasrkan hasil dari pengujian hipotesis diatas, diketahui nilai positive ranks $8^{\text {b }}$ berarti 8 siswa yang dijadikan sampel dalam penelitian, yang artinya nilai posttest lebih tinggi dari nilai preetest, sebanyak 8 orang siswa mengalami peningkatan secara signikasi dari preetest ke posttest, dengan rata-rata peningkatan sebesar 4,50 dengan jumlah keseluruhan sebesar 36,00. Berdasarkan tabel uji hipotesis dapat disimpulkan secara ratarata tingkat kepercayaan diri mengalami peningkatan, setelah mendapatkan perlakuan layanan bimbingan kelompok.

\section{PEMBAHASAN}

Kajian ini membahas pengaruh bimbingan kelompok dengan teknik diskusi dalam mingkatkan konsep diri positif siswa. Dalam angket pada saat preetest dan posttest. Sebelum diberikan layanan bimbingan kelompok dengan teknik diskusi rata-rata dari preetest sebesar 78,25 dalam kategori "Sangat Rendah", setelah diberikan perlakuan / treatment maka skor kepercayaan diri siswa dalam data posttest sebesar 96,25 dalam kategori "Sedang". Ini menunjukan karakteristik konsep diri positif yang dimiliki peserta didik sudah cukup bagus namun masih bisa ditingkatkan setelah adanya layanan bimbingan kelompok dengan teknik diskusi yang mempunyai skor rata-rata mengalami peningkatan skor sebesar 18,0 hal ini mengidikasikan sudah ada peningkatan dalam karakteristik konsep diri positif yang dimiliki siswa tersebut setelah layanan bimbingan kelompok dengan teknik diskusi.

Layanan bimbingan kelompok dengan teknik diskusi ternyata mampu meningkatatkan skor rata-rata sikap percaya diri siswa. Berdasarkan hasil rekapitulasi analisis deskritif pree-test menunjukan skor rata-rata seluruh sub variabel sebesar 14 dengan persentase sebesar 35\% dengan kategori Sedang. Hasil rekapitulasi analisis deskritif post-test menunjukkan skor rata-rata seluruh sub variabel sebesar 17,4 dengan persentase sebesar $43,2 \%$ dengan kategori Tinggi. Hal ini menunjukan adanya perbedaan atau perubahan skor yang mengalami peningkatan setelah adanya layanan bimbingan kelompok dengan teknik diskusi.

Layanan bimbingan kelompok efektif untuk meningkatkan konsep diri positif siswa. Karena dalam pelaksanaan bimbingan kelompok peserta didik sebagai anggota kelompok akan sama-sama menciptakan dinamika kelompok yang dapat dijadikan sebagai tempat untuk mengembangkan konsep diri positif. Anggota kelompok mempunyai hak yang sama untuk melatih diri dalam mengeluarkan pendapat, pikiran serta gagasan yang dimiliki untuk membahas suatu topik permasalahan juga bisa melatih kemampuan siswa untuk berani mengungkapkan pendapat dalam forum maupun untuk melatih kemampuan siswa belajar dalam berinteraksi sosial dalam kelompok.

Sejalan dengan hal itu Hartinah (2009: 104) menyatakan layanan bimbingan kelompok adalah layanan bimbingan dan konseling yang memungkinkan sejumlah peserta didik secara bersama-sama, melalui dinamika kelompok memperoleh berbagai bahan dari narasumber tertetu (terutama dari Guru pembimbing) dan atau membahas secara bersama-sama pokok bahasan (topik) sebagai individu maupun sebagai pelajar, dan untuk pertimbangan dan pengambilan keputusan atau tindakan pelajar.

Dalam penelitian ini peneliti dalam menerapkan layanan bimbingan kelompok menggunakan teknik diskusi. Teknik diskusi adalah salah satu cara atau model tertentu untuk pencapain tujuan. Diskusi merupakan pertukaran gagasan, pendapat, ataupun pikiran antara dua orang atau 
lebih secara lisan yang bertujuan untuk mencari kesepakatan atau kesepahaman gagasan atau pendapat. Hal ini dikemukakan oleh Muzdalifah (2014).

Berdasarkan temuan penelitian Iswari, A.D., Yusmansyah \& Andrianto, R. E (2019) bahwa terdapat peningkatan konsep diri pada siswa yang telah diberikan layanan bimbingan dan onseling kelompok menggunakan teknik diskusi. Hal tersebut dapat dilihat berdasarkan skor rata-rata posttest yang lebih tinggi dari skor preetest. Hal ini berarti bahwa layanan bimbingan kelompok efektif untuk meningkatkan konsep diri positif siwa.

Berdasarkan hasil penelitian yang terdahulu dapat menguatkan hasil yang peneliti peroleh dalam memberikan layanan bimbingan kelompok dengan teknik diskusi untuk meningkatkan konsep diri positif siswa.

Berdasarkan tabel uji hipotesis dapat disimpulkan secara rata-rata tingkat kepercayaan diri mengalami peningkatan, setelah mendapat perlakuan layanan bimbingan kelompok. Dari hasil yang diperoleh maka Ho ditolak dan $\mathrm{Ha}$ diterima. Dengan demikian, maka hipotesis dalam penelitian ini diterima, yaitu "Terdapat peningkatan yang signifikasi layanan bimbingan kelompok menggunakan teknik diskusi efektif dalam meningkatkan konsep diri positif siswa kelas XII AKL 2 SMK Muhammadiyah 2 Palembang sebelum dan sesudah diberikan perlakuan / treatment setelah diberikan layanan bimbingan kelompok.

\section{KESIMPULAN}

Berdasarkan temuan dan pembahasan diapat disimpulkan sebagai berikut:

1. Layanan bimbingan kelompok dangan teknik diskusi dapat meningkatkan konsep diri positif siswa.
2. Konsep diri positif siswa sebelum di berikan layanan bimbingan kelompok dengan teknik diskusi bisa dikatakan rendah dengan rata-rata 78,25 setelah diberikan perlakuan konsep diri positif siswa terjadi peningkatan dengan rata-rata 96,25.

3. Pelaksanaan bimbingan kelompok dengan menggunakan teknik diskusi dinilai efektif meningkatan konsep diri positif siswa. Peneliti memfokuskan pada pemahaman akan pentingnya konsep diri positif. Serta siswa di harapkan memahami kelebihan dan kekurangan diri untuk membentuk konsep diri positif yang baik dengan menonjolkan kelebihan tanpa menghilangkan kekurangan.

\section{DAFTAR PUSTAKA}

Arikunto. (2014). Prosedur Penelitian. Jakarta: Rineka Cipta.

Hartinah, S. (2009). Konsep Dasar Bimbingan Kelompok. Bandung : Pt Refika Aditama.

Iswari, A. D., Yusmansyah.,\& Andrianto, R. D. (2019). Peningkatan Konsep Diri Menggunakan Layanan Bimbingan Kelompok Dengan Teknik Diskusi Pada Siswa. ALIBKIN: Vol 7 No 5.

Muslifar, R. (2015). Efektifitas Pelaksanaan Layanan Bimbingan Kelompok Dalam Mengembangkan Konsep diri Positif. Jurnal Penelitian Tindakan Bimbingan dan Konseling. Vol. 1, No. 2, 58.

Nurihisan, A. J. (2017). Strategi Layanan Bimbingan dan Konseling. Bandung: Pt Refika Aditama. 
Prayitno. (2017). Layanan Bimbingan Kelompok Dan Konseling Kelompok. Bogor: Ghalia Indonesia.

Roestiyah. (2012). Strategi Belajar Mengajar. Jakarta: Pt Rineka Cipta.

Sayondari, P. N. (2014). Penerapan Bimbingan Kelompok dengan Teknik Diskusi Kelompok Untuk Meningkatkan rasa Percaya Diri Siswa Kelas VIII E SMP Negeri 3 Singaraja Tahun Pelajaran 2013/2014. e-journal Undiksa Jurusan Bimbingan Konseling Volume: 2 No 1, 4.

Sobur, A. (2016). Psikologi Umum. Bandung: Cv Pustaka Setia.

Sugiono. (2017). Metode Penelitian Pendidikan Pendekatan Kuantitatif, Kualitatif Dan RED . Bandung: Alfabeta.

Sugiyono. (2010). Metodelogi Penelitian Pendidikan Pendekatan Kuantitatif, Kualitatif, dan RED. Bandung: Alfabeta.

Sugiyono. (2018). Metode Penelitian Pendidikan Pendekatan Kuantitatif, Kualitatif, Dan RED. Bandung: Alfabeta.

Suharsimi, A. (2014). Prosedur Penelitian Suatu Pendekatan Praktik. Jakarta: Rineka Cipta.

Widodo, H. (2019). Pengaruh Bimbingan Kelompok Terhadap Perkembangan Konsesp Diri Positif Siswa di SMKS-PP Swasta Putra Jaya Stabat Kabupaten Langkat Tahun Pelajaran 2016/2017. Jurnal Serunai Bimbingan dan Konseling, 65.
Yusuf, A. M. (2017). Metode Penelitian Kuantitatif, Kualitatif \& Penelitian Gabungan. Jakarta: Kencana. 